\title{
Investigating neorurals and squatters'
} lifestyles: personal and epistemological insights on participant observation and on the logic of ethnographic investigation

\author{
Investigando estilos de vida de \\ neorurales y okupas: intuiciones \\ epistemológicas y personales sobre la \\ observación participante y la lógica de la \\ investigación etnográfica
}

Claudio Cattaneo Universitat Autònoma de Barcelona - Can Masdeu, Antic Camì de St.Llatzer - Barcelona claudio.cattaneo@liuc.it

\section{Resumen}

He utilizado una experiencia de campo entre In my PhD thesis in Environmental Science, I used comunidades neorurales de los Pirineos Ibèricos y una fieldwork amongst "neorural" communities in the Iberian experiencia directa de vida entre okupas urbanas en Pyrenees, and direct participation amongst "okupas" Barcelona para redactar mi tesis doctoral en Ciencias (squatters) in Barcelona, $I$ reflect on the two Ambientales. Analizo dos metodologìas (la observaciòn methodologies (ethnographic investigation and participante y la lògica de la investigaciòn etnogràfica) y participant observation) that I used, and I discuss their discuto su aplicaciòn con referencia al estilo y al application with respect to the style and to the particular contexto particular de la investigaciòn. La experiencia context of the investigation. The experience of living de vida entre las okupas de Barcelona nace within the Barcelona squatting community predated the anteriormente a la decision de realizar un trabajo de decision to do the rural fieldwork; so, I argue, the campo, asì que la distinciòn entre observador y distinction between observer and observed is purely observado se hace puramente artificial y discuto las artificial. I discuss the epistemological implications. implicaciones epistemològicas.

Palabras clave: Observación participante; Keywords: Participant observation; Ethnographic Investigaciòn etnogràfica; Observaciòn destacada; investigation; Detached observation; Participant Participante que observa; Transdisciplinaridad. 


\section{The basic experience}

This paper refers to the methodological chapter written for my PhD thesis "The Ecological Economics of Urban Squatters: a Barcelona case study- The Ecological Economics of Neorural Settlements in the Garrotxa, Catalonia", which is the development of the fieldwork experience made of up to 6 visits to Alta Garrotxa and of 4 years living amongst the extended urban squat community of Barcelona and of the park of Collserola. The most important visit to Alta Garrotxa has been during Easter time 2003: it took the form of a 12 days itinerary through the several houses between Monars and La Quintana, while the urban squatting experience is centred around the development of the project of Can Masdeu, squatted in December 2001 a month before my first arrival. My fieldwork experience is integrated by other 4 random visits to rehabitated rural villages in the Iberic regions of Navarra and Aragon the most important of which has been in September 2003 in occasion of the defence of Artozki: the Foral Navarre Government, under the Itoitz Dam Project, evicted its inhabitants, but a resistance followed after that, before being finally evicted and destroyed by the government.

\section{Origins of the fieldwork experience and considerations}

\section{around it}

The fieldwork experience has been, and still is, a particular experience where there is no distinction between normal life and research work. The reasons for this lay in the fact that to a certain extent I share values and ideas with the people living in rural houses and urban squats and I do respect their way of live, either in the so isolated mountains, either in the tense streets of downtown Barcelona. Also my visits to the mountains did not serve as ethnographic work only: first of all they were an experience of life for myself, but as well they served as a practical learning of a way of life, as a natural relief from the busy life of Barcelona city, as visits to people who first became acquaintances and finally friends, as entertainment during its traditional celebrations.

In the case of the Barcelona experience, with the project of Can Masdeu, the importance of the aspect of normal life, with respect to my research work is inverted. In academic terms I could say that there is an identification between object and subject of study where the academic work (Cattaneo, 2005a) and its terminology only represent one aspect of the reality of the experience: real-life experience is hence reduced to an academic language. Chronologically there has been an initial encounter with rurban (rural-urban) squatting in January 2002 that generated my decision to start a living experience in the Can Masdeu project; in spring 2002 was the decision to investigate neorural lifestyles in the mountain area of Alta Garrotxa, and later on the decision to include and compare other lifestyles like the ruralurban (rurban) experience that I was already living; finally this analysis was extended towards the wider squatter's context. So, the initial idea of writing something on the "neorurals" came after my admission in the Can Masdeu project and the initial contact to this reality came without thinking to any future academic utility. I should say, from a personal point of view, that this experience gains a much more important value for my life than it simply is as an academic duty; the academic outcome is a byproduct, a positive externality useful for the contribution to the diffusion of alternative living experiences within the academic community. From another complementary view, I hope that the PhD work will contribute, by providing the examples of practical applications of ecological economics (as well as political ecology, political economy and social ecology) to value -even if they are illegal and 
antagonist- neorurals and squatters alternative lifestyles, their defence and justification; for this scope, the exploration of the different methodological approaches is given here.

\section{Types of investigation and their epistemological implications.}

From a methodological standpoint, this mix of personal lives, academic work and political action can be related to four different contexts that I have used in this work. Two of them relate to two methodologies already codified:

participant observation, whose main reference for description is Oscar Guasch (1997), but that nonetheless is connected to the issue over the role of participative perspectives, argument of some debate in literature (Montenegro, 2001;Montenegro and Pujol, 2003) and that can be linked to the general idea of Situated Knowledges (Haraway, 1991) and extended to that of feminist epistemology (Fox Keller, 1985 and Harding, 1987) and to the social intervention

ethnographic investigation, whose main reference are Velasco and Dìaz de Rada (1997) and that also refer to the wider framework of qualitative research (Denzin and Lincoln, 2000).

The other two methodological contexts refer more to personal considerations that aroused during the field experience. I defined them as:

investigation with minimal impact and

participant observing.

However, these last two methodologies which aroused from personal considerations can be introduced within a wider methodological context that can suit them. I will briefly clarify what they could refer to before passing to the in-depth presentation of each approach. With total honesty I have to admit that running my research has been a pleasure for me, since during my visits and my stays I always felt part as a person before than as an academic. As an outcome, it resulted an investigation with minimal impact during my visits in Alta Garrotxa while in Barcelona I am feeling as a squatter (a participant) doing, amongst many things, an investigation (observing).

Given the above mentioned investigating contexts, and the latest evolutions in these fields I can refer in literature to what is known as, among other ethnographic practices, autoethnography (Denzin, 1997). Beyond autoethnography there are many other epistemological issues correlated to the role of the author in a research and in her product: with respect to power relationships in knowledge and to social intervention, Haraway's (1991:4) metaphor of being "In the belly of the monster" is an excellent example; with respect to the impacts according to the type of language used and with respect to selfcriticism reflexive methodology is another (Alvesson, 2004; Alvesson and Sköldberg, 2000).

Their contributions match with some aspects of my work. The fact that I am a squatter links directly my investigation to political action-research, which marks a connection with other works that emerge from a desire of social compromise and of non neutral thought as that of Colectivo Situaciones $(2001 ; 2002$; $2005 ; 2006 a ; 2006$ b). Is then my work a form of action or my political ideology is translated into an academic product? Critical Social-Psichology of Science (Iñiguez and Pallì, 2002) is an emerging subdiscipline addressing exactly these topics, while Critical Research (Fractalitats en Investigaciò 
Critica, 2005) questions the role of antagonist investigation from established academias. "Frente a la pretensiòn que la ciencia es immune a los efectos de los sistemas de valores y de que su desarrollo queda al margen de las creencias de los investigadores, la psicologìa social de la ciencia ha puesto de manifiesto algunos contextos y condiciones donde se aprecia su dependencia de las mismas" (Iñiguez and Pallì, 2002:19)

My works might fit within what Iñiguez and Pallì describe as the hew areas of social psychology of science. This subdiscipline, traditionally linked to the mainstream social psichology "de influencia estadounidense, metodologicamente quantitativa y de tipo individualista" (2002: 31), has recently developed also a postmodern approach. By rewieving a wide range of publications, the authors identify new themes such as the ideological character of scientific practice and propose, beyond other approaches, "una psicologìa social de la ciencia deconstructiva" where scientific practice is material and mundane just as other practices, breaking down the myth of reality as a concept of truth, and seeking the concept of "collective thought". Critical approaches to the established science that, after all, simply repropose the old scientific claim of openness and plurality.

Here follows a detailes description of the methodological approaches.

A]. Participant observation. Guasch (1997) defines participant observation in a very interesting way: "de todos los sistemas de investigación social, la observación participante es quizás el más subjetivo. Por eso la observación participante es un instrumento idóneo para recuperar el sentimiento en las ciencias sociales. Si los estereotipos del género fueran ciertos, resultaría que la observación participante es femenina: es flexible, dúctil, intuitiva, sutil, no racional. La observación participante opone al rígido positivismo masculino una tolerancia epistemológica que prefiere pactar la realidad antes que imponerla" (Guasch, 1997: 7).

I consider important here to give a look to what feminist epistemology has to say about "gender" and "science". Evelyne Fox Keller (1985: 177) looks at the roots of objectivty arguing that, with the arising of feminism it "came under suspicion as an androgenic goal. Some authors concluded that perhaps, after all, science is a masculine project". However, since many feminist writers, amongst whom Evelyn Fox Keller, Donna Haraway and Sandra Harding are also scientists, the idea of a masculine science should be corrected towards an idea "from within science, of science as a human instead of a masculine project and the renunciation of division of emotional and intellectual labor that maintains science as a male preserve"; arriving at such a new scientific vision would imply "a transformation of the very categories of male and female, and correspondingly, of mind and nature" (Fox Keller 1985: 177). Gender should not sussist in science; for example Harding (1987) recognises that men are not a priori excluded from making feminist science while Haraway (1991) talks about a postmodern society made of gender indistinct-machine correlated cyborgs.

The political essence of scientific inquiry is not denied in feminist science: Harding (1987) investigates the epistemological question of wheter politicized inquiry can produce more complete and less distorted research results. But also conventionally understandings of a hegemonic science are political: "all claims for intellectual egemony [are to be put] in their proper place -that we understand that such claims are, by their very nature, political rather than scientific" (Fox Keller, 1983:178). This idea of putting all claims in their proper place conducts us to Haraway's "postmodern insistence on irreducible differences and radical multiplicity of local knowledges" (Haraway, 1991:187) for which she would like "a doctrine of embodied objectivity that accommodates paradoxical and critical feminist science projects: feminist objectivity means quite simply Situated Knowledges" (1991:188). This 
pluralism of visions has a base in Harding's argument against the idea of a distinctive feminist method of research. "Can There Be Feinist Science? [No, but] only many stories that different women tell about the different knowledges they have" (Harding, 1987:189-190)

This issue develops further in Haraway untill the power correlations existing between different knowledges arising from different places (i.e. academic or local). But since the development of feminist epistemology run in parallel with the epistemological insights aroused during my research as a squatter amongst squatters, I will deal with them more deeply in section $D$ of this paragraph where I propose the new methodological framework of participant observing.

The origins of participant observation lay in the naturalistic vision of sciences like biology, zoology and botany, in which the scientist transfers herself in a natural environment and realizes a type of observation which is always subjective. A critique refers to the militancy that natural scientists do in favour of the protection of the studied species, militancy which is not allowed to social scientist: "se prescribe $y$ se premia al naturalista lo que se prohibe al cientifico social" (Guasch, 1997: 10). The ideas and the analytical perspective over this work have been inspired by a set of principles dissociated from the principles of western culture: when I attended a course in Environmental Ethics at the University of Edinburgh my teacher Justin Kenrick taught me of a revisited idea of progress which is not unidirectional. By my present understanding progress should move towards a balance of Nature and Technology; an inspirational element is our lost direct relation with Nature, commonly considered as something separated from our lives. By this vision western ideas of conservationism call for a tout court protection of special ecosystems but they exclude lives and culture of the traditional people who co-evolved over time within these ecosystems. Human presence is considered as a threat, and no value is given to the preservation of cultural diversity. For anyone as a person and as a "scientist", Nature is something that forms part of our lives, and our lives form part of nature. For these reasons, a recommended policy would be to consider and to accept neorurals and squatters' lifestyles because more than in respect of abstract systems such as authority and law they develop in respect of living material beings such as people and nature, that many naturalistic scientists would be happy to preserve and support.

With the personal reflection given above I want to clarify the subjectivity of this methodology and to justify an analysis with strong political values; these subjective environmental values have originated from something so "scientifically certain" as the reality of the present ecological crisis. "Si como propone Weber la acción humana es radicalmente subjetiva, su comprensión sólo puede conseguirse subjetivamente. El problema básico de la mirada sociológica es que la situación social del observador condiciona aquello que mira y aquello que ve." (Guasch, 1997: 11). Guasch suggests how the epistemological bias deriving from a subjective researcher could be reduced, and he recommends professional honesty. As every investigating subject is different, her social position, and her political values, should be explicitly clarified so to put a light on the question of subjectivity. Nonetheless this confession, necessary on one side, is not by itself sufficient to control the effects of the investigation, neither it is to clarify completely the author's socio-political distortion. The way to Knowledge in precise science is usually filtered by a measuring tool, while in social sciences it is filter by a subjective observer. On one side it is proper to describe the measuring tool, on the other it is correct to reveal subjective positions. But none of these epistemological paths will get to the understanding of pure Reality. This issue is as old as Parmenide's philosophy, or in other words "todo es subjetividad (sea como producciòn de subjetividad o bien subjetividad producida)" (Colectivo Situaciones, 2006a:1). 
Colectivo Situaciones, active in Latin America and interested in studying the political dynamics of their continent, openly defends subjective positions in research; their logic is that of investigation for and from the social movements. They are not only aware that their work is "un proyecto de lectura interna de las luchas [...] y no una descripciòn "objetiva"' (Colectivo Situaciones et al., 2001:1) but they even aim at this subjectivity of thought. Their aim is to generate a creating function and not anymore a simple reproduction of the existing world. This tension between creation and reproduction reminds me of art, specifically to the difference between some modern age and contemporary artists. While the first used to reproduce a "natura morta" on a paint exactly as it would look like in reality, contemporary artists are willing to generate reactions in the observers of any type.

In the following development of participant observation as a methodology of investigation, disciplines like ethnography and anthropology took an important and almost exclusive paper with respect to its use. Sociology was more and more oriented towards the separation between observer and observed reality, but the question of the social distance assumed an important weight in the methodological expositions. The separation is so frequent and so recommended in sociology that it exists a distinction between observer or interviewer and analyst, so that "sirve a la sociologia para evitar el compromiso social" (Guasch, 1997: 11). In the present case my social distance from squatters and neorural groups is deliberately minimum; in line with the anthropological tradition I am as much an observer as an analyst, and the problems of representation of the reality by an external agent are very reduced: "Con frecuencia sucede que las personas ajenas definen la realidad social de manera simple $y$ cartesiana y que los miembros de esa misma realidad elaboran definiciones más complejas y matizadas" (Guasch, 1997: 36). In spite of the existence of different opinions according to which it is preferable for the investigators to abstain from the direct participation in a social group (positions more typical of sociology, see for example Taylor and Bogdan in Guasch: 1997), in ethnography the opposite is defended because "no tiene demasiado sentido empecinarse en convertir lo facil en dificil" (Guasch, 1997: 37).

Another issue of participant observation is whether it will be part of an open or of an "undercover" investigation. An open strategy is one where the investigator "negocia y pacta su presencia en el escenario" (Guasch, 1997: 40), whereas an "undercover" investigation is recommended "cuando la realidad social que se estudia se oculta a los ojos del público general de forma deliberada" (Guasch, 1997: 41). In the case of this work the on-field presence in Alta Garrotxa has been both open and "undercover", depending from the people: for one side it was a series of visits to acquaintances who previously knew of my decision to make an investigation, and for other people it has been an occasion to observe. Some of the many people met (those who are the closest and best known) knew of my academic implication (some of them even hold a degree in environmental sciences), so that it has been possible to say that it was an open investigation, whereas other people understood my presence as a visitor who participated in the tasks, activities and recreational moments just as any other visitor: to this extent the investigation remained "undercover". The reasons of this are because some visits only lasted one day, or because I met some people only once. Other reasons why I did not openly declare my role of investigator are presented in part $\mathrm{C}$ of this paragraph and that I have defined "investigation with minimum impact". These points agree with what Oscar Guasch writes: "En cualquier caso, la distinción entre investigación abierta y encubierta suele ser más ideal que practica. Lo usual es que en toda investigación en la que se emplea observación participante sea abierta para unos ojos (los porteros y los informante) y cerrada para otros (la mayoría de los observados)" (Guasch, 1997: 42). 
It is time now to provide an epistemological analysis that I consider important and that originates from the development my personal philosophical interest and research path. It can be said that there are "two alternative paths to knowledge" and they originate a twofold epistemological problem. In fact, contrasting with participant observation, the methodology of normal science (Kuhn, 1962) looks for objectivity through the cancellation of the observer's interference in the experiment: the issue lays on the validity of what is scientifically called "experiment". I should note that while normal science states to be "value-free", every reduction of reality into an experiment implies remarkable value judgements from the role of the scientific observer. Moreover in the case at hand the object of observation Catalan neorurals, Barcelona squatters and their ecological economics- is a self-conscious reality formed by complex systems. In order to analyse the role of the observer in these alternative paths I considered the particular context of my field experience. This "playground" is a system where, from my point of view as an observer, reality is not only observed but also participated while, within the observed system, self-consciousness increases complexity as this recognises my presence. Finally, I was not only considered an investigator, but by someone also a friend. To become friend of some of the observed persons is not necessarily a methodological goal of the process, however this could also happen. In my case the friendship did not arouse as a consequence of the investigative process only, but as the result of time spent in common activities, events, gatherings, visits, etc.

The context of this work focuses on people and their lifestyles: as we said they can be represented as complex and self-conscious systems and that make it impossible for the observed reality not to be participated by the academic observer. The objective scientific condition where the observer does not intervene and does not interfere with the study is only a particular case. This particular case refers for example to Galileo's observation and measurement of Jupiter's satellites, made possible only by the introduction of the cannocchiale, an exosomatic apparatus ${ }^{1}$ that proved the validity of the heliocentric theory. Within quantum physics this theory tells the same whether the sky is observed by an experimenter or not, with or without a cannocchiale. Unfortunately Galileo's scientific method did not mention that this is a particular case that works under optimal conditions in a simple system, where the observer does not interfere within the observation and the elements of the observed reality are not self-conscious.

Post Normal Science reminds us that for complex systems the scientific methodology that reduces reality into an experimental model is not apt for the search of the "truth". Moreover, in the cases of urgent decisions where complexity is matched with high stakes, the opinion of experts should not be the only one to be evaluated by policy makers. Democratisation through the participation of lay people in the decision-making process is recommended. Democratising decision-making could be extended to the political issue of self-organization which is defended by squatters and neorurals as the way to manage their lives. As well self-organization is one of the defining characteristics of living systems. (Funtowicz and Ravetz, 1993; 1994a; 1994b; Ravetz, 1999). In the case of this fieldwork as a source of the ideas of the thesis, the system is a complex one, the "observed object" are people with conscience of themselves and of what kind of experiment is going on upon them, fact that might consequently affect them and "the results". In synthesis we are in front of trade-off: on one side objective observation, with its own methodological characteristics and on the other participant

\footnotetext{
${ }^{1}$ Former ways to knowledge, like Aristotelian science, were centered more on subjective observation rather than objective validation proved by the technical evolution of exosomatic tools (Cattaneo, 2005b).
} 
observation, with other new characteristics. In addition, we are in a new "playground" different from the one in which Galileo set the foundations of the scientific method.

The scientific method has its origins in the moment when Galileo, with the help of his new tool, the cannocchiale, observed the sky. If there are reasons for accepting his methodology for the observation of the sky, modern science still has to show the validity of this methodology for other types of objects of investigation. In fact Jupiter's satellites are very likely moving around in the same way whether there is nobody in the Universe watching at them, or someone is watching from some place; whether she is observing with her own eyes, or through a cannocchiale; whether she is disinterested, or interested in destroying geocentric theory. But when we are observing people there is an ontological difference because it is very likely that they will feel observed: people have self-consciousness of themselves as different from who looks at them; they understand the difference between being alone or being observed. Moreover people will feel different when they are observed in a disinterested way, from when the observer wants to test, study or measure something from them. With respect to the scientific method the investigation people has to acknowledge the complexity of this reality, very different from the case of linear movement around a planet.

Once this fundamental difference is recognised, then we are facing a trade-off: either we continue investigating with scientific "orthodoxy", we consider that the existence of self-consciousness in the research object is an irrelevant variable and we believe that as observers we can perfectly isolate ourselves from our object, or in alternative we evaluate Participant Observation as a new methodology for investigation. In the comparison between the two methodologies, we can find differences with respect to our role as investigators -are we sticking to the scientific methodological path?- with respect to the reaction of the observed -will she still behave naturally?- and with respect to the result of our investigation -what kind of reality are we discovering?

The following table clarifies this idea.

\begin{tabular}{|l|l|l|}
$\begin{array}{l}\text { Context: complex systems and } \\
\text { self-consciousness of the } \\
\text { research object }\end{array}$ & Detached Observation & Participant Observation \\
\hline $\begin{array}{l}\text { Fitness within the "normal" } \\
\text { scientific method }\end{array}$ & It respects the scientific method & $\begin{array}{l}\text { No, scientific methodology is } \\
\text { reductionist and is not adequate } \\
\text { for complex systems }\end{array}$ \\
\hline Reaction of the observed & $\begin{array}{l}\text { The observed is aware of being } \\
\text { within an experiment }\end{array}$ & $\begin{array}{l}\text { The observed behaves almost } \\
\text { normally }\end{array}$ \\
\hline Distortions method-reality & $\begin{array}{l}\text { Methodological soundness might } \\
\text { gives distorted images of reality. }\end{array}$ & $\begin{array}{l}\text { Distortion with respect to the } \\
\text { arisen where the observer forms } \\
\text { part of that same reality }\end{array}$ \\
\hline
\end{tabular}

Table 1: Differences between Detached Observation and Participant Observation in the particular research context of the field work experience.

This table justifies a use of the methodology which, according to conventional economic science and in order to explain the experience in economic terms, is not orthodox. The aim is to understand the economy in its original sense: oikonomía (from ancient Greek: oikos = house/community and nomos = 
management). Such oikonomia can be understood as the creation of a system of management of a house (or of a community or group). In situations where the house (or the community or group) represents a principal element around which life is created; such oikonomía, or system of management, is the representation of a lifestyle as is in the case of the groups analysed in this work.

Conventional economics tends to be reduced to monetary valuation, for this reason it is easy for it to be a hard science expressed in quantitative terms out of which is relatively easy to determine some mathematical functions that represent some type of economic behaviour; most findings in economics come from econometrics which literally means "measurement of the house/community". Different from conventional economics, my oikonomic investigation does not reduce to the quantitative measurement of some values, moreover money and monetary values have little relevance in squatters' lifestyles with respect to other economic means. Finally the type of investigation I run was to physically be in some oikos (urban and rural squats in this case) where I could get primary qualitative information -rather than extrapolating numerical values from some database as in econometrics. Under these circumstances my role could not be as detached as that of an econometrician; it would have been very hard to get numerical information and a study of lifestyles cannot be reduced to numbers as easily as, say, consumer preferences expressed by monetary consumption. Considering the quality of the final result I desired, I preferred to do participant observation rather than a detached observation.

It is clear that the understanding of modern economic science is that of crematística as Aristotle named it, which is "the study of price formation in the markets" (Martinez-Alier, 1991) and measures values reduced in monetary terms. Such reductionism - that can be criticized in the theory and cannot be proposed in the practical experience of squatters and neorurals' lifestyles- is allowed and favoured by the adoption of methodologies that detach the scientific observer from her model of investigation.

B]. Ethnographic investigation The base reference for this methodology is the work of Velasco and Dìaz de Rada (1997), who review many methodological contributions of different ethnographers and students from the discipline. However, this methodology fits within what Denzin and Lincoln (2000) define techniques of qualitative research.

Fundamental characteristic of this type of investigation is the fieldwork that "constituye la fase primordial de la investigaciòn etnogràfica" (Velasco and Dìaz de Rada, 1997: 18) and it is related to the participant observation which "no serìa posible fuera del trabajo de campo" (Velasco and Dìaz de Rada, 1997: 19). Also Oscar Guasch (1997) explains to us that "la etnografia no es la observaciòn participante, sino su resultado" (Guasch 1997: 12). The personal impressions of the methodological context in the fieldworks of Alta Garrotxa and Barcelona are in line with the three points of methodological originality that Edgerton and Lagness (mentioned by Velasco and Diaz de Rada, 1997: 23) describe and that will be here analysed.

The first point of originality is the personal implication of the ethnographer in the work that, opposing herself to the model magistrate-that-interrogates looks for egalitarian relations through participant observation. "El primero parece contemplar la permanente posibilidad del engaño y trata de neutralizarla con el ejercicio de la autoridad, el segundo desconfía de la información obtenida en condiciones formales y neutraliza el engaño a base de vivencia directa, de convivencia" (Velasco and Dìaz de Rada, 1997: 25). This perspective completes the methodological characteristics exposed in Table 1 and, as for the authoritarianism, clarifies the necessity of coincidence between an antiauthoritarian methodological perspective, based in the shared experience and the deepest squatters and neorurals' values. 
Another point of originality of the fieldwork is " que una cultura debe ser vista a través de quien la vive, además de a través del observador científico" (Velasco and Dìaz de Rada, 1997: 23). This is the case of the fieldwork in general but it is particularly evident in the Barcelona experience. Lévi-Strauss noticed that the "laboratory" experiences that in a fieldwork are already prepared and that cannot be manipulated, can at least be replaced through an inductive process by models that represent these experiences, and that "la audacia de semejante procedimiento (reemplazar) es compensada, sin embargo, por la humildad con la que el antropólogo practica la observación" (mentioned by Velasco and Dìaz de Rada, 1997: 31). As Velasco and Dìaz de Rada also clarify "Situarse en el punto de vista del "nativo" es quizás la expresión menos ambigua del acceso a la significación, es la conquista de la objetividad por medio de la capacidad de formar inter-subjetividad" (Velasco and Dìaz de Rada, 1997: 31).

The last point of originality is the apprehension of totality, with which the ethnographer tries to reproduce in its work the culture observed in its totality. Clearly this ideal cannot be completely satisfied as there are obvious relativity problems: the observer for example does not have the gift of the omnipresence and ubiquity; she is not related to all the people; only she will visit some places and villages of a culture or of a people. In addition, the concept of " culture of one people as everything" can not exist within the same investigated population: "la cuestión está en si el sentido unitario de la cultura es sólo perceptible desde dentro, desde el punto de vista del nativo, o si más bien la percepción de conjunto corresponde a una perspectiva exterior, [...] resultado de un constructo intencional" (Velasco and Diaz de Rada, 1997: 37). This is what clearly happened in my fieldwork in Alta Garrotxa -that represent a subgroup of the neorural areas of all Pyrenees, and in the same Garrotxa region many other houses exist that I have not been able to visit but, as Herskovits says (mentioned in Velasco and Dìaz de Rada) "Nadie negará que las variaciones [locales] existen, pero [...] son mucho más relevantes las diferencias entre modos de vida de culturas diferentes considerados como todos" (Velasco and Dìaz de Rada, 1997: 37). Nevertheless there exist fundamental techniques for the production of information: "a) la observación y la observación participante proporcionan descripciones, es decir, discurso propio, del investigador; b) la entrevista, tejida sobre el diálogo, proporciona discurso ajeno, de los sujetos de estudio." (Velasco and Dìaz de Rada, 1997: 34). As a result of the visits to the mountains both of these techniques have been reproduced. The first one, observation, refers to activities and to means employed in the day to day life; subsequently these are analysed in terms of production and consumption patterns; an "economic" issue indeed, which is "the investigator's own speech". The other technique, informal interview in the forms of dialogues and conversations provides more directly people's views about their ethical values or the motivations that mark their lifestyle. In ethnography a debate exists over the different theoretical expositions that give form to different strategies for the production of information. Different theories have been formulated with respect to the functions of the ethnographic work. The functions are describing, translating, explaining and interpreting. Without entering the debate that the different theoreticians had and still have, the scope is to describe how this work fits within the different mentioned functions and its meaning with respect to them.

Ethnographic reports are often abundant in descriptions, as expert story-tellers ethnographers explain facts and details with an ability that can give the readers the impression of being in there (LeviStrauss, 1955). Unfortunately in my case it is not the case and the function of description does not represent a central part of my work. Even if the originality of squatters and neorurals' lifestyle could require an in depth description of the observed reality, for two reasons this function has not been developed as much as it would be the case. The first reason is given by the goal of the thesis which 
focuses on ecological economics analysis; the other is the lack of any ethnographic formation with which the function of describing is penalized with respect to the other ones. Without any doubt description is at the base of any ethnographic work, it is the equivalent to the experiment in exact sciences: the results do not have scientific sense without an exact description of the type of experiment made. What is important in a good description is its role as a source of usable information for the remaining three functions, so that in the work there are random examples that have an excellent meaning in the approach of the economic theory (production and consumption patterns) and which deserve a description. Nevertheless many other cases that, although interesting and meaningful, did not have direct relevance to the spirit of the ecological economics work have not been described.

The ethnographic function with more space in the final work is translating. According to EvansPitchard (mentioned by Velasco and Dìz de Rada, 1997) the translation is "revivir una experiencia en forma crítica e interpretativa", transcribing it "en las categorías y valores de su cultura [del investigador] y en función de los conocimientos de su disciplina" (page 51). What Evans-Pitchard explains is exactly my personal case in my academic work: to translate, through an ethnographic fieldwork, the experiences which in the "work" have been lived in the values of the investigator's culture, in this case is a quite radical school of ecological economics, and based on the knowledge of my previous training as a business economist. Beyond this conjunction between the dominant economic thought, radical ecological economics and fieldwork experience in squatters and neorural groups, there also exists the coincidence between observer and observed (explained in part D of this paragraph). These characteristics of my field-work and from my academic training might be useful to support, facilitate and clarify the translation task: from one side I am not an expert ethnographer but at least I am very familiar with the squatting experience since I form part of that movement; from the other side I have an understanding and a critical knowledge of the basic economic concepts. In the explanation of Velasco and Dìaz de Rada, (1997) translating is exactly this: gathering a distinguishing language that the investigator has been learning in the fieldwork or, as in this case, that she knows like her own; talking about Evans-Pitchard's definition, they comment: "esto es traducir, y más propiamente, traducir una cultura en términos de otra. El ejercicio de traducción no solo se aplica a sociedades primitivas, sino también, en las modernas sociedades complejas, a [...], "subculturas", muchas veces con lenguaje propio, distintivo" (Velasco and Dìaz de Rada, 1997, page 51). Also, in the words of Oscar Guasch (1997), when one talks about the social distance, he explains that: "el pertenecer a un grupo social evita los problemas de traducciòn cultural" (page 11) and "Desarrollar la práctica etnográfica en el propio medio cultural permite minimizar (aunque no obviar) los problemas de interpretación y de traducción cultural" (Guasch, 1997, page 14).

In extreme synthesis, the aim and hope of the investigation is to present the coincidence between squatters and neorurals' lifestyles with a type of ecological economics, as it is literally understood as the ecological way to manage the house (oikonomics).

The results of the translating function are explained in comparative terms. From one side the reality of the fieldwork experience, described with practical examples, has been translated into a theoretical language of alternative economics. On the other side there is what already exists within the present construction of the academic economic theory: different interpretations and reductive modelling of the reality. In synthesis a practice of ecological economics is explained by comparing it with the economic theory of the dominant system. In a metaphor, different oikonomiae are explained as different paths towards the satisfaction of human needs. So, the neorural and squatter evidence, translated 
(theorized) as an ecological economy, is explained as a path towards need satisfaction. This path, compared with the mainstream path, looks more sustainable (sustentable). Velasco and the Dìz de Rada (1997) talk of "ethnography like allegory".

The last task is interpreting. Although they do not necessarily appear in an ethnographic work like successive, nor as related the one to the following one, they seem to be so in this work. Considering this task like "decir algo sobre algo" (Velasco and Dìaz de Rada, 1997: 71), the interpretation given to the facts of the fieldwork experience is a questioning of the validity of the dominant theoretical foundations, now that the existence of newly discovered alternatives has been certified. Preceding to the interpretation, these experiences had simply been explained in comparative terms of ecological economics versus crematistics as different paths towards need satisfaction.

The questioning is a deeply rooted, genuine one, of ethical and political nature: "if both paths lead to the same end, and the newly discovered path seems to be a sustentable one, then why it is given such a hard life from the mainstream political visioning?" There is a switch from an economic explication to a political interpretation. The interpretation is in terms of policy. The policy of selforganisation, which is defended in the final analysis. To talk about self-organization presupposes a strong ethical and political discourse but this is totally rejected (even if implicitly present!) in the foundations of neoclassical economic science. As Velasco and Dìaz de Rada (1997: 59) clarify, "De antiguo, explicación e interpretación se han presentado como alternativas en la distinción entre ciencias de la naturaleza y ciencias del espíritu [...]; así como en la definición de las ciencias sociales -y en concreto de la antropología- como ciencias o como artes". With reference to the investigation, the comparison (explanation) between two economic paradigms is based on real facts, observable and potentially measurable and verifiable, typical operations of a science; as well, "to say something on something" (to interpret) over the universal validity of the dominant neoclassical economic paradigm comes closer to what can be an ethical and philosophical positioning, that is, a science of the spirit or, in a certain sense, an art.

For the final redaction of the thesis I am planning to use the four tasks of ethnographic investigation in different chapters, contributing to create part of its skeleton. However this is not a clear cut task, especially for the description because any particular aspect of reality which is described is there for a reason, while other aspects are not: how to communicate that the described facts have an important meaning for me, with respect to the argument that I want the reader to follow, and therefore I reproduce in the text? As well, the use of a particular vocabulary familiar to an economist is used here in a completely different context, for instance the non-money based lifestyles of squatters and neorurals. "Awareness of the problematic nature of all language use is as crucial as is neglected in research" (Alvesson and Deetz, 2000 mentioned in Alvesson, 2004: 29): how to bridge the gap between description and explanation? Is there enough descritpion of particular episodes in order to pass on to the translation? Sometimes it has been difficult to resist the temptation to limit only to the descritpion and wait another chapter for the translation and the explanation, even if for methodological order it would look good to maintain a clear structure. However, on the other hand, dealing with the description of an episode of squatters' lifestyle and its explanation straight after that gives a sort of continuity to the argument. The choice between what to describe and the rest of reality which is not marks the gate of reduccionism and gives the researcher a kind of responsibility towards his readers. And once the choice is made, it still remains the choice of which language to use and the understanding that all this implies for the readers, an element in reflexivity. (Alvesson and Sköldberg, 2000). 
At the beginning I had in my mind an ideal sequence of ethnographic functions to structure my work, however some melting occurs between the chapters/functions and an analogical fuzziness results. Every chapter is like a combined plate with four ingredients (the ethnographic functions) and each function is a main ingredient, but not the only one, for its chapter. The overall storyline is as follow: description of squatters and neorurals' lifestyles; translation, as an inductive process, towards "radical ecologicl economics"; explication as a new sustentable path towards needs satisfaction and finally interpretation of a policy of self-organization. In particular I understand economics as a mean and need satisfaction -which provides economic utility- as the end.

The final work is a continuity between the tasks of description, translation, explanation and interpretation: first some facts of real lives are randomly and briefly described; they show a particular ethnographic interest. Soon they are translated into the theory of a radical ecological economics which is the closest academic paradigm to these lifestyles. Next is the explanation of what this reality, with an own theoretical foundation, means when compared to another reality that stems from the theoretical paradigm of the dominant system's economy: it is a sustentable materialistic path alternative to the dominant virtual path marked by increasing money flows (and in specific by real estate speculation denounced by Barcelona squatters). Finally, the possibility of interpretation (saying something over something), leads towards comments and questions regarding the validity of a unique economic thought which is challenged by the proposed policy of self-organization, a condition typical of living dissipative systems (Nicolis and Prigogine, 1977; Prigogine and Stengers, 1979; Shrödinger, 1967). Might this be a solution to the social and environmental crisis? Lacking any certainty about absolute truths, the answer is that this represents a temporal local solution, probably sustentable.

Velasco and Dìaz de Rada (1997) consider the ethnography as form of representation, either of a culture or in general allegorical terms; in this case the representation of a culture seems to have less weight than the interpretation as an allegory. Three are the reasons. A practical one: squatters and neorurals' culture is no different from the western dominant one, their education is in general a Christian one; cultural elements such as monotheism and monogamy are questioned but they are subconsciously present by default. This is a limit and a challenge for them, for their personal growth and mainly for the next generation and the educational values that will be given to their children. The second reason refers to the purpose of this work, that does not want to talk about an exotic culture, but wants to fit a way of life within a real world, in critical and comparative terms, like an "exercise of the cultural critique" (Velasco and Dìz de Rada, 1997: 84). Finally a pedagogical one: squatters and neorurals are common people who want to show that anyone can make the change in their life if they are willing to. Should they be represented by any investigator as a special culture, maybe that of ecological superheroes or social saints would have the terrible consequence of creating a myth that serves only to the dreams of common people and that would mark a hierarchy between who wants, can and does and who dreams but knows that can not. An example can explain it all: we all probably know the symbol of Ernesto Che Guevara printed on t-shirts. Once I have seen one where el Che was depicted with two huge Mickey Mouse ears and at the bottom a writing recommending to avoid believing in symbols or waiting for another hero to come. After all el Che was simply a unique person who fought for his ideals, the problem is that some dreamers made a global myth out of him. As a byproduct a huge capitalist merchandising industry has been created. Should el Che know about this probably he would "turn in his tomb".

The passage from studies of distant and primitive societies to present marginalized cultural groups in our complex society has also given strength to the sense of cultural critique; if in the first cases this 
had "the primary objective to show the cultural diversity", in "the domestic" cases "they begun to deliberately look for the cultural critique" (Velasco and Dìaz de Rada, 1997: 84). This modern way to make cultural critique develops through a comparative exercise that is what has previously been explained with respect to the explanation of squatters and neorurals' ecological economics as a sustentable path.

Connecting the methodology of cultural critique to civilization with the original cultural characteristics of primitive and of farmers societies there are three points to be highlighted: 1) at an ecological level, the "respect for nature lost with civilization", and the utopia of the ecological paradise; 2) at a socialhuman level, the "communitarian lifestyle, to close personal relationships" and 3) at a spiritual level, the "sense of the sacrum[... ], the rituals, the festive sense of life" (Velasco and Diaz de Rada, 1997: 86). It has also been discovered that "la indiferenciación entre instituciones sociales (política, parentesco, economía, religión, etc.), propia de las sociedades preindustriales, no es una deficiencia social. Lo que lleva a pensar que la diferenciación - y a veces la fragmentación- de las instituciones en Occidente no es un fenómeno necesario para el funcionamiento y el mantenimiento del orden social" (Velasco and Dìaz de Rada, 1997: 86). One of the main findings of the investigation confirms the validity of this statement: western economic theory is based on the differentiation between production patterns from one side and consumption patterns from the other; the differentiation between institutions such as consumers on one side and producers on the other. Instead in the squatters and neorural society such exosomatic differentiation exists in a limited way when these groups relate within the market. Unfortunately my theoretical background does not allow me to translate these life experiences in a purely anthropological analysis of a cultural frame; rather they are directed towards the above mentioned comparative economic analysis

The lack of a theoretical background, and of practical knowledge on how to lead an ethnographic work are the reasons why the investigation got disconnected from the ethnographic model proposed by Velasco and the Diaz de Rada. In fact the process of ethnographic investigation suggests a distinction between "fieldwork" and "structured desktop work" and in several other elements such as the "project", the "fieldwork diary", the "election" and the "entrance in the field", the "notebook", "observations", "interviews"... Such elements also are supported by ethnographic material like photos, records, notes, notebooks, diaries.... This series of necessary steps and tools is not completed in my work; apart from a yellow notebook in which I took note of everything I could write down and apart from my memory of the fieldwork experience and my knowledge of the people previous to the visits, there is no other form of storage of the "primary information". In fact the project of the investigation emerged from the lived reality of personal day to day life and it slowly became integrated with such way of life. The initial idea was to create a participative social multicriteria model over different management alternatives for the Alta Garrotxa area, but at that time the initial squatting experiment put roots into a way of life which begun to be valued as feasible, sustentable and enjoyable. Political values behind personal academic work shifted the investigation objective towards defending that particular way of life. Finally a four-year long squatting experience (unforeseen at the beginning) made it possible for the doctoral thesis to expand from the neorural (rural and rurban) analysis into the urban squatters.

C]. Investigation with minimal impact. This term refers to a type of methodology that could be considered as the integration of participative observation (point A) and that has particular relevance for the fieldwork experience in Alta Garrotxa: when I was there doing my investigation

I was also there as a visitor. On the other hand the "investigation - life experience" in the urban context of Barcelona is more relevant with methodology $D$ (participant observing). 
In order to describe the methodological characteristics of participative observation I should consider the perspective of the observed: if the presence of the observer is participative, the observed will feel less affected by the artificiality of the observed-observer relation, and will feel more involved in a peerto-peer relation. For example, in the days of permanence in Alta Garrotxa, a talk on the legal and institutional problems of squatting a public house would have two different connotations: one would be the case of Mauricio, neorural of La Quintana, speaking openly and honestly to Claudio, squatter from Barcelona; the other is the case of Mr. Cattaneo, academic investigator sent from UAB to conduct a formal interview with Mr. Dusen inhabitant of one old masía of the Girona pre-Pyrenees. There is no difference from participative observation apart from the specific context of the identities of the observer and of the observed: if they are close enough, the investigation can be done with minimal impact. This is a pseudo-methodology referring more to a particular style of investigation adopted during my permanence in the fieldwork. The particular style of investigation has, nonetheless, some technical implications, and an example, that refers to the technique of the interview, follows.

There is less need for a pre-organized interview (which has the advantages to be easier to be codified than a flowing conversation) if it is compensated by the observer's closeness to the values of the observed and that allows the latter to run an investigation with minimal impact. While an interview requires a previous effort for the preparation of a series of questions over objectives, purpose, context, etc., a free conversation requires an effort a posteriori where the useful information for the investigation is selected and where interesting values are expressed.

\begin{tabular}{|c|c|c|}
\hline & Advantages & Disadvantages \\
\hline Formalized interview & $\begin{array}{l}\text { Easy to codify according to the } \\
\text { research objectives }\end{array}$ & $\begin{array}{l}\text { Sense of artificiality for the } \\
\text { observed/interviewed person }\end{array}$ \\
\hline Free conversation & $\begin{array}{l}\text { The "truth" comes out in a natural } \\
\text { way. Topics re-define the } \\
\text { orientation of the investigation }\end{array}$ & $\begin{array}{l}\text { Might not comply with all the } \\
\text { research objectives. } \\
\text { (Compensated by the fact that } \\
\text { the research objective might co- } \\
\text { evolve towards what is said) }\end{array}$ \\
\hline
\end{tabular}

Table 2: Advantages and disadvantages of formalized interview and of free conversation

The table represents how the difference between both methodological approaches has advantages and disadvantages for the observer and for the observed. In the technique of the interview the observed is the one who feels the disadvantages, whereas in the free conversation the observer takes most disadvantages. The intensity of the advantages and disadvantages depends clearly on the objective of the investigation. For example, an investigation with a quantitative objective as the measurement of the energy cost will have less problems of objectivity than a qualitative investigation such as the analysis of the ethics laying behind the decision to return to a life in the country. As well, this second type of investigation can be modelled and its objectives might co-evolve with what is said in a conversation, or in the day to day: the objectives of an investigation about a lifestyle might not need to be fully determined a priori "on the desk", as in the methodology of ethnographic investigation; rather they are a fuzzy set of objectives the determination of whose might come a posteriori, as the result of the actual fieldwork experience. For the purposes of my investigation there was no particular need for an interview preparation to determine further specific objectives: it seemed that the points of originality in the squatters and neorurals' lifestyles are by themselves enough for the final production of the results of the investigation. The codification of the results of the investigation (previously defined 
as the task of translation) is an emergent process, in fact the objectives of the investigation matured during the fieldwork experience. For example before the fieldwork in Alta Garrotxa I knew I was going to analyse production and consumption patterns, but I could have not planned to test the relevance of "endosomatic patterns" because I could not imagine that something like taking an infusion with herbs from the garden can be considered a particular type of production and consumption pattern. Only later I understood that having a working brake with a herbal infusion is an act of enjoyment that could be considered an "endosomatic pattern" without money; and that this enjoyment is equivalent to watching television, act that is generated by an "exosomatic production and consumption pattern" that implies the production of a television, creation of television programmes and the consumption of lifetime watching the television and of lifetime sold in the labour market. After all the final investigation is a qualitative discovery of lifestyles where some production and consumption patterns are "endogenised". By doing so the result resembles an ecological economy.

Emergent investigation objectives found their roots in the effort, as an investigator, to direct the conversations towards what was interesting to listen and got finally ripen during the posterior analysis. I felt it was useless for the research, but even less useful for a good relationship to ask questions such as "Did you have to come living here because the city oppressed you?" "What do you believe in?" or "How many goats do you have? How many do you kill per year? How many were born? How many did you have the previous years? How many do you eat? How many do you give? How many do you sell? How many kilos of meat for each goat? And now: what about pigs, donkeys and chickens?" A particular perception of common sense prevented me to make a professional research. At the time of one of my visits the goats just managed to enter the garden eating most of the winter vegetables. Instead of making an interview on goat management I preferred to help building a better fence around the garden. Finally, while I am not sure of what is the marginal contribution of an interview on goats, I have a clearer idea about the marginal contribution of fencing the garden

In a free conversation the investigator can confirm the hypothesis of the overwhelming city if the observed person spontaneously talks about it and by how often or intensely she talks about. As well as while fencing the garden I discovered that goats are kept for companionship more than for business, that for the following year the intention was not to have them anymore, that love for the animals gave value to an animalist ethics that, in the case of an interview previously prepared, might have not been considered as an hypothesis of investigation

As a matter of investigation style I had the feeling that as an academic observer I was the one who had to fill the gap of observation-understanding-codification because I was the one "landing" in that mountain area with something already in my mind. So I felt that I had the moral duty to bear all the effects of the investigation and that I had to cause the minimum disturbance to the observed people who already have a hard life living where they are. The less I could affect their day to day life the better I felt was the quality of the observation. I can provide a couple of examples to defend this argument. One is when a member of the community gardens of Can Masdeu interviewed by a university investigator ended his answer asking if he said it right: a doubt might arise whether he answered his truth or, knowing the interviewer was an ecologist, if he tried to answer what he thought was the ecologist's truth. The other example is given by Badal (2001: 21), a deep connoisseur of the neorural community and also a member of it. He explains the personal point of view of some neorural people with respect to academic investigators: " lo que es prácticamente seguro es que casi nadie aceptaría ser "objeto" de investigación de algún equipo universitario que aterrizara en alguno de estos núcleos. De hecho se han dado varios de estos casos, con resultados distintos: desde una buena 
relación o colaboración hasta "patadas en el culo" o "portazos en los morros"'. A similar recommendation can be found in the words of Oscar Guasch when he presents the practice of participant observation: "La vida cotidiana se convierte en el medio natural en que se realiza la investigación. Es una investigación que se pretende lo menos intrusiva posible, y para la que resulta imprescindible delimitar el tipo de participación que el investigador desarrolla en el campo y en los distintos escenarios" (Guasch, 1997: 35).

D]. Participant observing. In participant observation the logical subject is the observation, hence the focus is, like in western science, on objectivity. Participant observing is a logical game of words where the subject is the participant who lives a reality that he later observes. Hence the focus is on subjectivity. This last statement makes that this methodology is deeply a non-scientific one, possibly at the edge of academic recognition, but at the edge of academia is also my condition of a participant: through the observation of the reality that I live I dedicate time to produce an academic work.

I think is important to stress on this difference. In participant observation the researcher chooses an object of observation and gets close to it by participating in it. She leaves the academia and goes down to the social reality she is willing to participate in. Eventually she would like her work to promote social change: critical postures feel a social compromise in their work, even if they recognise that they come from the "Belly of the Monster" (Haraway, 1991; Montenegro and Pujol, 2003; Fractales de Investigaciò Critica, 2005).

In participant observing the participant to a social project chooses to reproduce her living reality and gets close to a research institution. From her social reality she goes in to the Belly of the Monster to hand in what seems to be the result of an observation.

I am grateful to my PhD supervisor for recommending me to follow an inductive process, moving from a particular participated reality into a general analysis of political economy. I consider that the loss in objectivity is compensated by a gain in commitment; that the loss in exact knowledge might be substituted by a gain in insights. Participant observation and participant observing arrive to the same reality, which after all we could consider as the network connection between partial knowledges, but they start from opposing perspectives with different purposes. An apple is an apple whether it comes from the agro-industry or it grows from a wild apple tree, but they exist according to different origins and eventually according to different purposes. While participant observation is an objective action that makes an observer landing into a fieldwork and only later this person becomes a participant, the participant observing is a person already embedded in her own day to day reality who only later decides to make an observation: her living reality is dis-embedded from the object of study.

Participant observing is another pseudo-methodology that puts into evidence the problem of the living subject who conducts an experiment. While western scientific methodology is willing to reduce the elements of subjectivity -task that is not possible beyond a certain point, participant observation, but even more clearly participant observing stress exactly on the non eliminability of the subjective bias towards objectivity. In the words of Shrödinger (1967: 137) "The world is given to me only once, not one existing and one perceived. Subject and object are only one. The barrier between them cannot be said to have broken down as a result of recent experience in the physical sciences, for this barrier does not exist". This statement sounds inevitable as the inevitability of life on both sides of existence and of perception; life is present both in the object and in the subject, in the reality and in the study of reality. By quoting Sherrington (1940) Shrödinger identifies two epistemological paradoxes referring to the relationship between mind and the world: "one world crystallizing out of the many minds" and "one 
mind, based ostensibly on the many cell-lives or, in another way, on the manifold sub-brains" and recognises that "both paradoxes will be solved (I do not pretend to solve them here and now) by assimilating into our Western build of science the Eastern doctrine of identity. Mind is by its very nature a singulare tantum. I should say: the over-all number of minds is just one. I venture to call it indestructible since it has a peculiar time-table, namely mind is always now. There is really no before and after for mind. There is only a now that includes memories and expectations. But I grant that our language is not adequate to express this, and I also grant, should anyone wish to state it, that I am now talking religion, not science -a religion, however, not opposed to science, but supported by what disinterested scientific research has brought to the fore." (Shrödinger 1967: 145)

The study resulting from this investigation, far from conceiving an objective reality, stresses on the unity and coincidence between subject and object; is inevitable and produces a political /ideological work. For these reasons I would think of participant observing as a feminist way to do science, for its partiality, for its emotional implications, for the necessary power inequalities between the lived -and not only experienced!- social reality and the academic world. Far from giving exact statements, it accepts critical questioning in order to generate a debate.

Colectivo Situaciones adopts a methodology coming the closest to this position, for its approach and for their compromise with social movements: are they political activists or observing intellectuals? They like to define themselves as militant researchers but, far from considering this as the central issue, they clearly want to avoid that "el resto de las modalidades practicas de intervenciòn se transformen en investigaciones" (Colectivo Situaciones, 2005:1). The central issue remains in the practice; they see autonomy arising as a practical element, "autonomì como funciòn de autoproducciòn y autovalorizaciòn de las luchas" distinct from "autonomismo como cristalizaciòn caricatural o doctrina sobre las luchas y los movimientos" (Colectivo Situaciones, 2006b:1).

A final explanation of participant observation versus participant observing is given through an example. Actually, this is the example where the original idea of "participant observing" was originated. During a house meeting the decision at hand was whether to buy or not a chainsaw; my personal vision before the debate was not to buy it, but I did not feel to have a strong position against the purchase. Since I was sitting in the same circle as every house member, we could consider that I was at least doing an observation. Since every house member was aware of my presence, we could consider that I was at least doing participant observation. Being a house member, and everybody knowing this, I had the right to express my opinion, I had the right to vote, and the right to put a veto on the decision. These rights have the potential to influence, with different degrees, the final decision so that we could imagine a fuzzy continuum of possibilities moving from simple observation, towards participant observation (an opinion is expressed) and finally to active participation (a vote is given, and eventually a veto is expressed).

The resulting decision was to buy a chain saw, and my participation remained limited to observation as I did not have a strong opinion against purchase. I could state in my thesis that rurban squatters own chainsaws. Had I vetoed this decision, maybe being the only one against purchase, my participation would have had more impact. Had I decided to write in my thesis that some rurban squatters do not own chainsaws, I would have made an observation strongly influenced by my participation. A member of Can Masdeu argued that extensive use of veto decisions could lead to "the tyranny of minority". 
By stating this, I want to highlight the dangers of such a methodology explaining why I defined this as a non-scientific one. The big issue here is: "how far can a participant have the right to produce an observation (for example an academic work) if her participation can influence the final outcome of the events?" And on the other hand, "how far should her participation be limited to observation?" This is to admit that the biasing potential of a participant who observes is high, but that at the same time the resulting reality that I could describe to my reader is always biased by someone's stronger opinion whether she is the academic who writes the study or any other member of the house.

\section{Practical application of the methodologies.}

The techniques employed to make use of the different methodologies will be described in this paragraph. The first part refers to the rural experience in Alta Garrotxa, characterised by short and sporadic visits and by very original lifestyles; the second refers to the Barcelona experience of life, longer, continuous and closer to typical urban lifestyles.

\section{Rural context: annotation by activities, means and discourse}

In the part of the work in the Garrotxa area a main norm has been followed: to imagine oneself as an ethnographer and to take note of everything. By doing so, participant observation in the style form of an investigation with minimal impact marked the rhythm of noting down things on a notebook. There are similarities with the process of investigation in ethnography that Velasco and Diaz de Rada (1997) present, but many points of divergences exist, mainly due to the author's ignorance in the practice of the ethnographic discipline. Some of these investigating failures have a justification; in their words: "los modelos han de identificar una práctica, pero sin ahogar con un exceso de recomendaciones la capacidad del que la lleva a cabo para comprender su objeto con la mayor concreción posible" (Velasco and Dìz de Rada, 1997: 91), or with the exemplary words of Spradley "el siguiente formato que sugiero refleja la organización que yo mismo he encontrado más útil" (mentioned in Velasco and Diaz de Rada, 1997: 91).

In the case of this investigation there was not a previous plan nor a model of what it was needed to be written down; rather the reality of being there was determinant in how to structure all the information that could be gathered. In order to maximize the input of information- but also for my personal curiosity- there were days dedicated to work a little with each person or with each group; it was important to listen to all conversations and sometimes I started a conversation; in other moments, especially when inputs reached a maximum or an inspiration occurred, I had to isolate myself to note down all the details of what had just been said, done or inspired. In order to diminish my investigation impact, or for a question of style, I never appeared in front of any person with pen and notebook: the quantity of input and the possibility to find a secluded place to note things down determined the frequency of writing down some notes.

The categories under which the information was collected were randomly suggested by the contingent reality: it seemed to me that a good way to take note was to distinguish between activities, discourse and means employed and this constituted what we know as the field diary. However, this way of organizing information might sound too straightforward for the expert in ethno-sociological research, as reality is never so clear-cut delimited between activities, means or discourses: as a researcher I might have forced some episodes to fit within my methodological structure. The reader might consider 
this way of fitting into categories as a personal mistake, of a non-user; but with some reflexivity I might consider myself as acting both ingenuously and genuinely. The result might be an interesting case of "what an inexpert would do on field", since the way of conducting my diary was more the way I used to write a personal diary in my childhood than the result of professional learning or experience. Ingenuous. But at the same time -now I am going to attempt a self-psycho analysis when I am not a psychologist!- if I haven't got a clear idea of how to do my mental organization is often that of reducing into logical structures ${ }^{2}$. The adoption of categories and blocks is a first filter that arises naturally when I am organizing external information for future elaboration: it is like the logic of a computer's directory, but is how my brain runs in his genuine way. But nonetheless these categories turned out to be useful for the oikonomic analysis that followed my fieldwork.

By another chance this tri-partition turned out to be useful to be codified within the scope of my work, whose title became "production and consumption patterns and discourse analysis." In detail, "activities" can be understood as physical labour, or time management, or organization of the work, or production management and can, in general, be identified with what is a production pattern. Activities is the mainly physical work in order to survive in a neorural life. Discourse refers to the ethics, the ideas and motivations that lay behind the material experience of life, as it would come out from informal conversations. As well is the discovery of a life ethic at the base of personal choices like beginning a neorural life. As well some conversations served to complete the information I could not get from the simple observation, such as which main activities were done in other times of the year. These informal interviews were useful to understand the psychological environmental ethics such as why did these people left the city, why did they choose that life, technically, why did they opt to change their consumption and production patterns. Finally "means employed" can be understood as the technology employed in the production for the future satisfaction of needs or as the pattern of resource consumption in the actual phase of satisfaction of needs, such as in the moments of rest, of free time, of socialization, alimentation and leisure in general. They refer to the economic means of production which, day by day, make possible a neorural life.

I consider important to open here a parenthesis on the insights I have gained by using this kind of methodology for my field diary. The main characteristic of neorurals and squatters' production and consumption patterns (and in general of those people who live with little money and in groups or communities) is not only the reduced use of resources and of technology but, at an upper level, also a different type of patterns. In fact some patterns are often invisible, they do not exist, they refer to what is not produced neither consumed to satisfy the same categories of needs. The idea of "production and consumption patterns" comes only with the industrial society of undifferentiated mass consumption, when human needs started to be satisfied by products who tended to: be increasingly produced by an exogenous institution like the market; accessed with a monetary purchase (with the complementary human ecological impact of a marginal increase in the sale of lifetime to someone else in the labour market); produced by artificial technological processes; sterile processes disconnected from the biological processes of the living organic world. In the experiences of my present research production and consumption patterns can be discovered only after "wearing analytical glasses" and they cannot be described from the simple observation and description of reality. These analytical

${ }^{2}$ For example my training background before a degree in business and economics is scientific studies at high school, where I excelled in mathematics and sciences and had some problems in literature and arts. 
glasses are for example those of the mainstream economist who distinguishes at a macro level between aggregate demand and supply, and at the micro level between consumer theory and production theory, where in both cases money is the central and only pillar.

This conceptual mark is a recent analytical invention where: a) the concept of consumer and of producer has been created; b) a separation between them has been created; c) this artificial system works measuring all possible values in money; d) the subjective value of production and of consumption are forced into the objective value of money. This analytical model has been also criticised in feminist literature (Waring, 1994), while in anthropology Levi-Strauss (quoted in Velasco and Diaz de Rada, 1997) talks about models as systems of symbols that represent the properties typical of the experience but that, differently from the experience, we are able to manipulate (Velasco and Diaz de Rada, 1997: 31).

What mainstream economists do not see is economics without money, hence the need to wear those analytical glasses is artificially created and super-imposed in any decision of political economy. When in my investigation I tried to wear those analytical glasses I discovered that consumption and production might well be eliminated, and still human needs could be satisfied. The elimination of production and consumption patterns was something more and beyond, under an ecologicaleconomics perspective, the idea to make them more materially and energetically efficient. The result from the evidence is that production and consumption can be endogenous (embedded, autonomy from the system, more typical of neorurals) or at a lower degree, if still exogenous, at least independent from the market and from the sale of lifetime (autonomy from the money, more typical of urban hunter gatherers who recycle).

\section{Urban context: real experience}

Methodologically this experience refers to auto-ethnography, however first of all it was born as a practical experience which was later been translated into theory. There are interesting contributions from critical social psychology with reference to self-investigation: "Una potencialidad de la investigaciòn critica es romper la logica sujeto que investiga-objeto de investigaciòn, posibilitàndose la investigaciòn desde una misma [...] Quien investiga se torna en el investigado/a" (Fractalitats en Investigaciò Crìtica, 2005:139). However in my particular case the coincidence between researcher and researched is not completely bi-directional, since the object of research is the squatting and neorurals community and I am only a part of it, in the case of the investigation in Can Masdeu I am a bigger part of it. Still the researcher is only me, while the cases of Fractalitats en Investigaciò Crìtica or of Colectivo Situaciones have the intrinsic characteristic of being also communities of militant researchers.

The above mentioned style of "investigation with minimal impact", the decision not to run any formal interview with pen and paper was in partly due to the fact that neorurals in Alta Garrotxa knew my status of urban squatter from Barcelona. At the same time, the condition of me being a squatter helped me to get a closer understanding of living in extreme conditions such as those of the neorurals in Alta Garrotxa. But how, being already a urban squatter, determined the investigation in the Barcelona context?

The urban field experience is a very genuine one. It has not been contaminated by research objectives: the social scientist who takes the role of becoming a member of the specific social class she wants to study is still becoming a member of that class under the condition of running a fieldwork. 
If the term "field-work experience" is still representing something external, exogenous, detached, with another game of words this term could be inverted into "house-life insights" that served as the base for an economic analysis of a way of life.

Another inversion refers to the step that ends in the academic product: a typical fieldwork experience is anticipated by an a priori analysis of what has to be searched for by considering the final research objective. In this case, 4 years living amongst urban squatters has been considered, a posteriori, a long enough experience in order to write a thesis on their ecological economics.

The urban experience is a meta-experience: during what we might still call a fieldwork in Barcelona I kept on studying ecological economics and my contribution to the Can Masdeu project has been influenced by what I learned on the way. To this extent the "ecological economics of urban squatters" might be affected by the impact of my physical work and of my academic learning: as already expressed, this is a matter of "participant observing", and an open question remains on how far, this way of producing academic work, is a bias. However, the application of this methodology in the urban context has highlighted a trade-off between a bias in academic validity versus a bias in acting for social change. Some insights from Montenegro (2001:11) can help us in understanding the bias between academic work and real participation. When she talks about situated knowledges and the responsibility for social intervention she argues that "la tensiòn surge cuando nos preguntamos còmo podemos actuar (intervenir o constituirnos como agentes politico de transformaciòn social) [...] que es lo que es necesario transformar y còmo se hace? [...] el debate entre el realismo de las perspectivas participativas y el relativismo del construccionismo social es un reflejo de las discusiones en las ciencias sociales". Discussions that, in order to solve the dilemma, are taking time away from real social action; but from the situated knowledge of a squatter, the question arising is: how much does social change need to be planned? An interesting thing is that I am aware of the "talking too much" dilemma not from reading too many papers in social sciences, but from within Can Masdeu itself. In fact there have been several house meetings dealing on deciding how to talk about an issue: Anglosaxon pragmatism of some Can Masdeu squatters has criticized this way of planning change, arguing that "the revolution is happening".

As well, in some of Barcelona's street protests organized by the squatting movement I have received an insight on how to arrive quickly to social change, a typical protest scream says: "Recull la rabia!" (Collect your anger!). Emmotions beyond discussions; historically many revolutions have been driven from hunger and anger before than consensus was reached.

\section{References}

Alvesson, Mats. (2004). Knowledge Work and Knowledge-Intensive Firms. New York: Oxford University Press.

Alvesson, Mats and Deetz, Steve. (2000). Doing Critical Management Research. London: Sage.

Alvesson, Mats and Sköldberg, Kej. (2000) Reflexive Methodology. London: Sage.

Badall, Marc. (2001). Nucleos rehabitados y experiencias de autoabastecimiento. Baez: Internacional University of Andalucia. 
Cattaneo, Claudio. (2005a). Los estilos de vida de I@s neorurales, esquemas de producciòn y consumo y anàlisis del discurso. MSc thesis: Universitat Autònoma de Barcelona.

Cattaneo, Claudio. (2005b) Some thoughts on t(T)ime, energy and their power-entropy relations: physical and social implications in bioeconomics. Poster presented at the conference on Complexity and Ecological Economics, Liverpool, England.

Colectivo Situaciones (2002). 19 y 20: apuntes para el nuevo protagonismo social. Buenos Aires: Situaciones. Available from www.situaciones.org Last accessed: 21-9-2006

Colectivo Situaciones. (2005). Nuestros Propòsitos Cuadernos Situaciones, 4 Available from www.situaciones.org Last accessed: 21-9-2006

Colectivo Situaciones. (2006a). Pròlogo al texto Subjetividad y Politica. Buenos Aires: Tinta Limòn Ediciones. Available from www.situaciones.org Last accessed: 21-9-2006

Colectivo Situaciones. (2006b). Hay una nueva gobernabilidad?. La Fogata, 1 Available from www.situaciones.org Last accessed: 21-9-2006

Colectivo Situaciones; Benasayag, Miguel; Brandt, Ulrich; Gonzàlez, Horacio; Holloway, John; Matini, Luis; and Negri, Antonio. (2001). Contrapoder, una introducciòn. Buenos Aires: Situaciones Available from www.situaciones.org Last accessed: 21-9-2006

Denzin, Norman. (1997). Interpretative ethnography: ethnographic practices for the 21st centruy. Thousand Oaks: Sage.

Denzin, Norman and Lincoln, Yvonna. (Eds.) (2000). Handbook of qualitative research (2.ed.) Thousand Oaks: Sage.

Fox Keller, Evelyn. (1985). Reflections on gender and science. London: Yale University

Fractalitats en Investigaciò Crìtica. (2005). Investigaciòn Crìtica: Desafìos y Posibilidades. Athenea Digital, 8, 129-144. Disponible en http://antalya.uab.es/athenea/num8/fic.pdf

Funtowicz, Silvio and Ravetz, Jerry. (1993). Science for the post-normal age. Futures, 25 (7), 739755.

Funtowicz, Silvio and Ravetz, Jerry. (1994a). Emergent complex systems. Futures, 26 (6), 568-582.

Funtowicz, Silvio and Ravetz, Jerry. (1994b). The worth of a songbird: ecological economics as a post-normal science. Ecological Economics, 10, (2) 197-207.

Guasch, Oscar. (1997). Observación participante. Madrid: Centro de Investigaciones Sociologicas.

Haraway, Donna. (1991). Situated Knowledges: The Science Question In Feminism And The Privilege Of Prtial Perspective. In Simians, cyborgs and women: the reinvention of nature. London: Free Association Books.

Harding, Sandra. (Ed.) (1987). Feminism and methodology: social science issues. Milton Keynes: Open University.

Iñiguez, Lupicinio and Pallì, Cristina. (2002): La Psicologìa social de la Ciencia: Revisiòn y discusiòn de una nueva àrea de investigaciòn. Anales de psicologìa, 18 (1), 13-43 
Kuhn, Thomas. (1962). The structure of the scientific revolution. Chicago: University of Chicago Press.

Lévi-Strauss, Claude. (1955). Tristes Tropiques. Paris: Libraire Plon.

Martínez-Alier, Joan. (1991). La ecología y la economía. Mexico DF: Fondo de Cultura Económica.

Montenegro, Marisela. (2001). Conocimientos, agents y articulaciones. Una Mirada situada a la intervenciòn social. Athenea Digital, 0, 1-11. Available from http://antalya.uab.es/athenea/numo/tesis-marisela.htm

Montenegro, Marisela and Pujol, Joan. (2003). Conocimiento Situado: Un Forcejeo entre el Relativismo Construccionista y la Necesidad de Fundamentar la Acciòn. Revista Interamericana de Psicologia/Interamerican Journal of Psychology, 37 (2), 295-307.

Nicolis, Grègoire and Prigogine, Ilya. (1977). Self-organization in Non-equilibrium Systems: From Dissipative Structures to Order Through Fluctuation. New York: Wiley.

Prigogine, Ilya and Stengers, Isabelle. (1979). La Nouvelle Alliance. Métamorphose de la Science. París: Gallimard.

Ravetz, Jerry (Ed.) (1999). Special Issue: Post-Normal Science. Futures, 31 (7)

Sherrington, (1940). Man on his Nature. Quoted in Shrödinger, Erwin. (1967). What is life? Mind and Matter. Cambridge: Cambridge University Press.

Shrödinger, Erwin. (1967). What is life? Mind and Matter. Cambridge: Cambridge University Press

Velasco, Honorio and Dìaz de Rada, Angel. (1997). La lógica de la investigación etnográfica. Madrid: Editorial Trotta.

Waring, M. (1994). Si las mujeres contaran - Una nueva Economía Feminista. Madrid: Vindicación Feminista.

\section{Historia editorial}

Recibido: 10/04/2006

Primera revisión: 11/09/2006

Aceptado: 22/10/2006

\section{Formato de citación}

Cattaneo, Claudio (2006). Investigating neorurals and squatters' lifestyles: personal and epistemological insights on participant observation and on the logic of ethnographic investigation. Athenea Digital, 10, 16-40. Disponible en http://antalya.uab.es/athenea/num10/cattaneo.pdf. 
Claudio Cattaneo. Licenciado en Economia e Commercio (1997) y con un MSc in Ecological Economics (2001) sus principales experiencias de trabajo salariado han sido montando escenarios por conciertos, en un auto lavaje, en consultaría estratégica de empresas, conduciendo un bicirickshaw y como profesor de Economía Ecológica. Ha viajado por toda Europa, a menudo en autostop o bicicleta y tiene una experiencia de viaje en Australia durante un año. En los años pasados ha hecho atletismo a nivel competitivo mientras que ahora se dedica a actividades físicas al aire libre y a la practica del yoga. Desde cuatro años vive en Barcelona frecuentando el doctorado en Economía Ecológica y okupando en una masía en un proyecto de vida comunitario y autogestionario. Entre otras cosas trabaja como voluntario reparando bicicletas, ofreciendo charlas, cultivando con técnicas agro-ecológicas, organizando eventos sociales y festivos en el barrio y participando en campañas y acciones de militancia política.

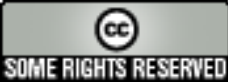

Este texto está protegido por una licencia Creative Commons.

Usted es libre de copiar, distribuir y comunicar públicamente la obra bajo las siguientes condiciones:

Reconocimiento: Debe reconocer y citar al autor original.

No comercial. No puede utilizar esta obra para fines comerciales.

Sin obras derivadas. No se puede alterar, transformar, o generar una obra derivada a partir de esta obra.

$\underline{\text { Resumen de licencia }}$

Texto completo de la licencia 